\title{
The New Data on Stratigraphy of the Riphean Stratotype in the Southern Urals, Russia
}

\author{
V. N. Puchkovi,2, A. A. Krasnobaev³, N. D. Sergeeva1 \\ ${ }^{1}$ Institute of Geology, Ufimian Scientific Centre of RAS, Ufa, Russia \\ ${ }^{2}$ Bashkirian State University, Ufa, Russia \\ ${ }^{3}$ Institute of Geology and Geochemistry, Uralian Branch of RAS, Ekaterinburg, Russia \\ Email: puchkv@ufaras.ru
}

Received April 2014

\begin{abstract}
A recent series of $\mathrm{U}-\mathrm{Pb}$ age determinations of zircons (SHRIMP, IDTIMS) from volcanic flows of several levels permitted to refine stratigraphy of the Riphean of Bashkirian megaanticlinorium (Urals, Russia), and provide a better correlation of this straton with the International and Chinese scales of the Proterozoic.
\end{abstract}

Keywords

Proterozoic, Stratigraphy, U-Pb Dating, Zircons, International Stratigraphic Scale, Riphean

\section{Introduction}

The Upper Proterozoic deposits of the Riphean and Vendian of the General Stratigraphic Scale of Russia (GSSR), widely exposed in the Bashkirian Megaanticlinorium BMA) of the Southern Urals, can be approximately correlated with the Meso- and Neoproterozoic of the International Stratigraphic scale (ISS) (Stratigraphic schemes of the Urals; 1993, The Stratotype of the Riphean, 1983; The Geologic Time Scale, 2012), or Sinian to Changcheng succession of stratigraphic units of China. In the last years, after the International excursion to BMA, with participation of the Chinese and Korean stratigraphers (Field trip Guide..., 2006), the work of dating of volcanic rocks of the Riphean section was strongly activated owing to a considerable progress in technique of isotope research. The work was stimulated by understanding that the International Scheme of division of Mesoand Neoproterozoic into systems/periods of equal duration (200 Ma) contradicts to traditional principles of stratigraphy, with elaboration of a system of stratotypes and GSSPs in real sections, with application of methods of chemostratigraphy, event stratigraphy, micropaleontology and other approaches (Bleeker, 2004). The understanding that the existing chronometric stratigraphic scale of the Precambrian needs an up-to-date chronostratigraphic revision, based on global events, becomes now stronger (Geologic Time Scale..., 2012; Grazhdankin \& Maslov, 2013), though the Meso- and Neoproterozoic scale in ISS is still unreformed.

Volcanic eruptions are developed at three levels of the Riphean section of BMA and their dating is of a spe- 
cial importance for determination of ages of host deposits and stratigraphic boundaries (Figure 1, Figure 2). Lava flows, characterized by low-grade metamorphic alterations, are developed in the Navysh subformation of the Ai Formation of the Lower Riphean, in Mashak Formation of the Middle Riphean and Arshinian series of the Uppermost Riphean. The latter was formerly attributed to the Lower Vendian in the Unified schemes of the Urals (Stratigraphic..., 1993), but it turned out to be a mistake. The series belongs to the Uppermost Riphean. The position of dated comagmatic dikes and other intrusive bodies support in some cases the stratigraphic conclusions. Recently, the dating of tuff layers, discovered in the Upper Vendian (Grazhdankin et al., 2011; Levashova et al., 2013)—548.2 \pm 7.6 and $547.6 \pm 3.8 \mathrm{Ma} —$ do not disagree with the suggested improvements of the Riphean stratigraphy of the Urals.

\section{Volcanics of the Navysh Subformation}

The determination of the age of these volcanics is critical for the precise age of the lower boundary of the Riphean. The bottom of the Riphean section is situated at 200 - $400 \mathrm{~m}$ lower than volcanics, at the base of polymictic sandstones of the Ai Formation (Burzyanian series), which overlies strongly metamorphosed ArcheanPaleoproterozoic Taratash crystalline complex with an angular unconformity (Figure 1, Figure 2).

According to earlier data, acquired with a complex application of the K-Ar, $\mathrm{Rb}-\mathrm{Sr}$ и U-Pb methods, the age of the Navysh complex was determined at $1615 \pm 45$ (Krasnobaev et al., 1992). For many years, this date was used for determination of the Lower boundary of the Lower Riphean in different stratigraphic schemes including the stratigraphic scheme of Russia (Shurkin et al., 1990) and the Urals (Stratigraphic, 1993), and also a Scale of geological time (Harland et al., 1985) at the level of 1650 Ma.

Owing to the development of modern methods and instruments for isotopic research, we have got a chance to check this date and make corrections. In the year 2011 well-preserved zircons were obtained from a sample No 2152 of volcanics of the Navysh complex (trachybasalt porphyrite to the SE of Arshinka village, 55 31'41.7"N; $059^{\circ} 40^{\prime} 48.5^{\prime \prime} \mathrm{E}$, at the western limb of the Taratash uplift (Figure 1). U-Pb analysis of them at SHRIMP II (VSEGEI) supported the impression of a good preservation of the zircons, showing very close and practically concordant ages after different isotopic ratios for the majority of crystals and "cluster" position of their analytical data near the concordia (Figure 3). For all 14 crystals that were studied (including the altered ones) a discordia was obtained with parameters $T_{1}=1752 \pm 18 \mathrm{Ma}$ and $\mathrm{t}=227 \pm 94 \mathrm{Ma}$, MSWD $=1.01 . \mathrm{T}_{1}$ may be interpreted as an age of the volcanics, and $\mathrm{t}$ - as a result of their "late Uralian" syn-orogenic alterations. We corrected the $\mathrm{T}_{1}$ date choosing the crystals which experienced minimal alterations, i.e. with the parameters which are the closest to the "primary substance". The age $\mathrm{T}_{0}$ calculated for these crystals is $1752 \pm 11 \mathrm{Ma}$, which corresponds to the age of the volcanics in a maximal degree (Krasnobaev et al., 2013).

This time mark is an indicator not only for the Navysh volcanics, but also for the lower boundary of the whole Riphean section of the Southern Urals. It does not contradict to a date of the last episode of granitisation under conditions of the amphibolite facies in the crystalline basement of this region: $1777 \pm 79$ Ma (Krasnobaev et al., 2011) and is also in accordance with data (Sindern et al., 2006) on the minimal age of granites of the Taratash complex (1800 Ma). Therefore the age of the base of the Riphean is in the limits of 1750 - $1800 \mathrm{Ma}$.

\section{Volcanics of the Mashak Formation}

During a long time the ideas of the age of the Mashak Formation of the Yurmatinian series (the lowest Formation in the Middle Riphean) was based on two methods: Rb-Sr (1346 \pm 41 Ma, whole rock) and U-Pb (zircon, classical dating, based on a great number of grains) $1350 \pm 30$ Ma (Krasnobaev et al., 1985). It was a reason for these authors to accept the age of the Mashak Formation and the base of the Yurmatinian series as $1348 \pm 30$ Ma. This time mark was for a long period of time an official date for the base of the Middle Riphean (Semikhatov et al., 1991; Stratigraphic..., 1993). Now our ideas concerning the age of the Mashak Formation have changed (Puchkov et al., 2009, 2013; Krasnobaev et al., 2013).

In the year 2008 two zircon samples from Mashak rhyolites were analyzed by U-Pb CA-IDTIMS method in the Boise University (USA) and the dates of $1381.1 \pm 0.7$ Ma and $1380.2 \pm 0.5$ Ma were obtained (Puchkov et al., 2009) (Figure 4). It was close to the precision date of the Main Bakal dike, sampled by us and analyzed in the isotope laboratory of the Toronto University (Canada): $1385.3 \pm 1.4 \mathrm{Ma}$ (U-Pb method, baddeleyite). The dike cuts the Bakal Formation and is comagmatic to the Mashak basalts. The Berdyaush rapakiwi pluton and Kusa-Kopan mafic intrusion — other types of comagmatic complexes of the same Formation (Ernst et al., 2006 


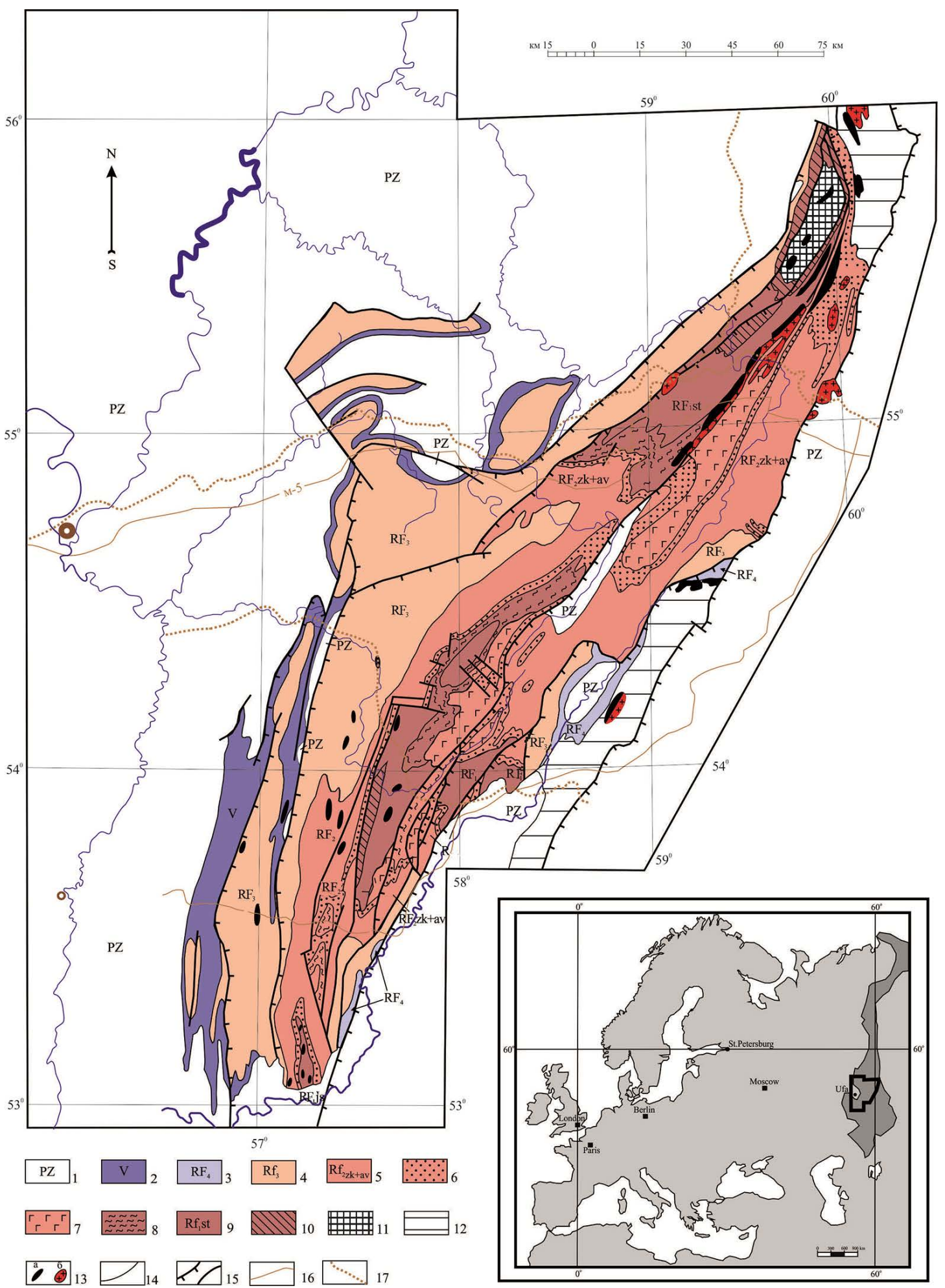

Figure 1. Geological map of the Bashkirian anticlinorium After Geological Survey map... 2002, strongly modified. 1Paleozoic, 2-Vendian, 3-Uppermost Riphean, 4-Upper Riphean, 5-Middle Riphean, Zigazino-Komarov and Avzyan Formations, 6-Zigalga Formation of the Middle Riphean, 7-Mashak Formation of the Middle Riphean, 8 - 10-Lower Riphean: 8-Bakal and Jusha Formation, 9-Satka and Suran Formations, 10-Ai and Bolsheinzer Formations. 11Archean-Paleoproterozoic Taratash complex. 12-Upper Riphean Northern Uraltau complex. Intrusions: 13a—mafic, 13bgranitic, 14—stratigraphic contacts, 15—-tectonic contacts: thrusts and normal faults, 16—highways, 17-railroads. 


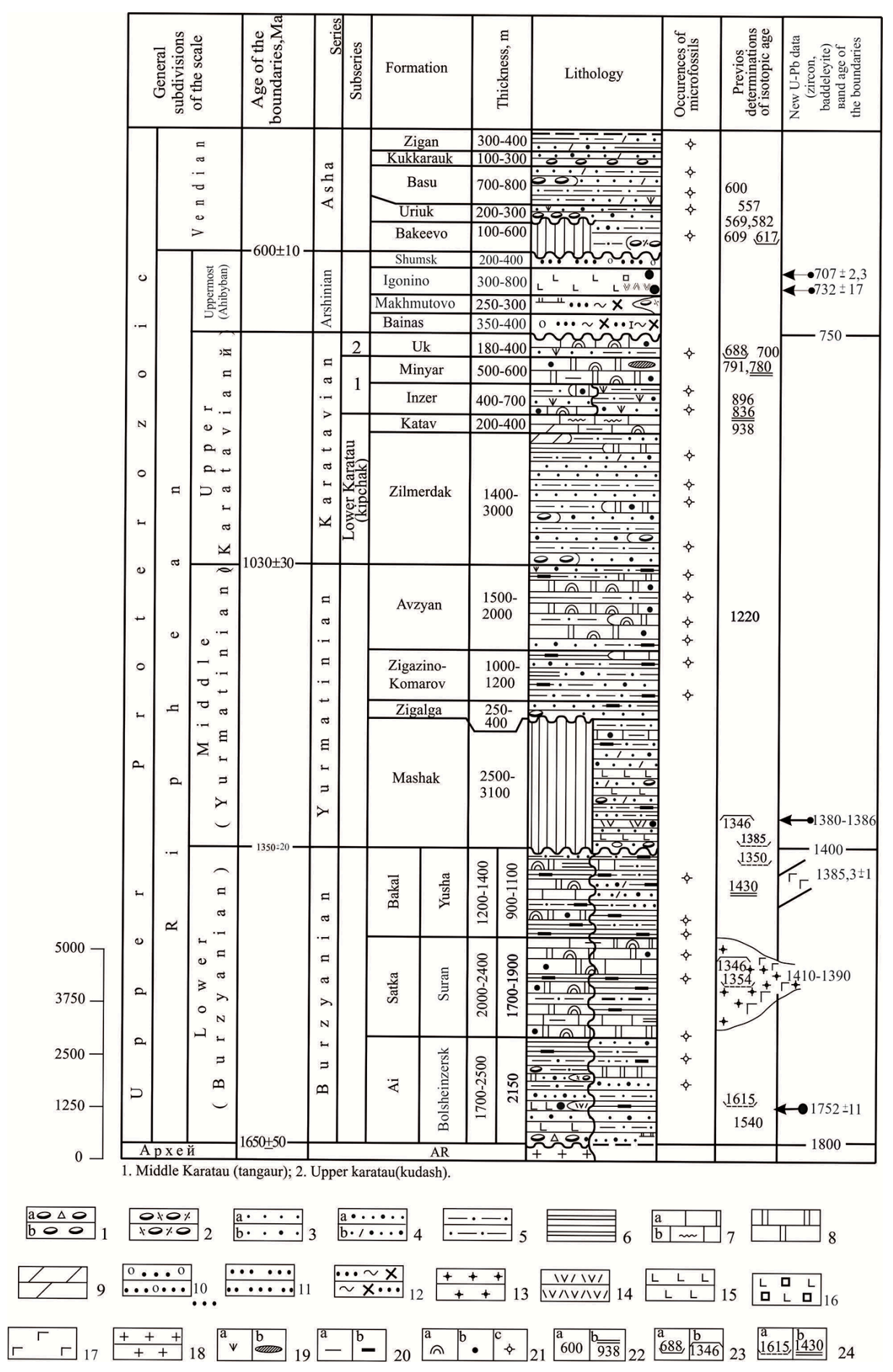

Figure 2. General stratigraphic scheme of the Upper Proterozoic deposits of the Bashkirian meganticlinorium (Southern Urals). After Geological Survey map...2002, strongly modified 1-conglobreccias (a), conglomerates (b); 2-polymictic conglomerates; 3, 4-sandstones: 3—quartz (a) and feldspar-quartz (b), 4—arcose (a) and polymictic (b); 5-siltstones; 6shales; 7-limestones (а) и striated limestones (b); 8-dolomites; 9-marls; 10-quartzite-sandstones with gravel; 11quartzite-sandstones and quartzite; 12-mica-chlorite-quartz slate; 13-granites; 14-rhyodacites, 15-metabasalts, 16-metabasalt porphyrite; 17-gabbro; 18-highly metamorphosed rocks of the crystalline basement; 19, 20-rock characteristics: 19-glauconite (a) and chert (b), 20-with clay component (a), carbonaceous (b); 21—органические ocrajrganic remains: stromatolites (a), microphytolites (b), microfossils (c); 22 - 24-Isotope age (Ma), methods: 22-K-Ar glauconite (a), whole rock (b); 23-Rb-Sr: glauconite (a), породы (b); 24-U-Pb zircon (a), Pb-Pb carbonates (b). 


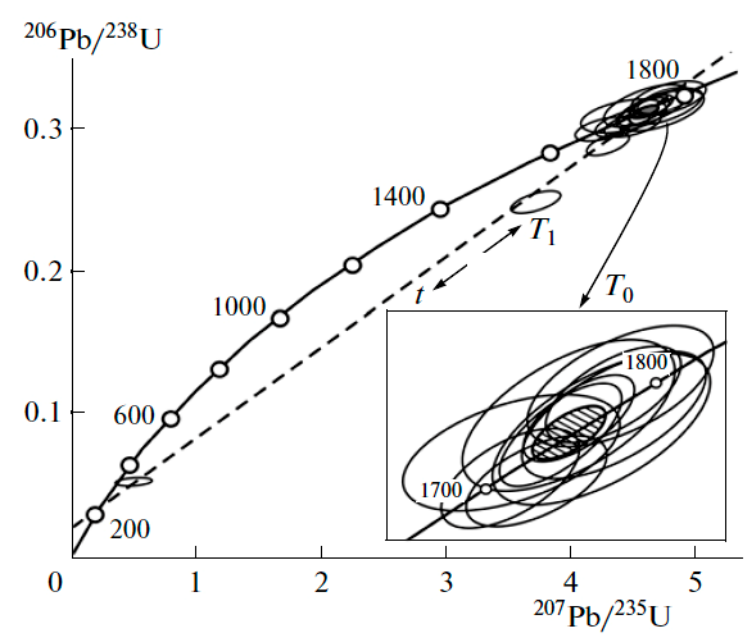

Figure 3. Zircons from trachybasaltic porphyrite (Sample 2152) of the Navysh Complex (Krasnobaev et al., 2013 a). Parameters of discordia: $\mathrm{T} 1=1752 \pm 18 \mathrm{Ma}, \mathrm{t}=227 \pm 94 \mathrm{Ma}, \mathrm{MSWD}=$ $1.01 ; \mathrm{T} 0=1752 \pm 11 \mathrm{Ma}, \mathrm{MSWD}=0.12, \mathrm{P}=0.73$.
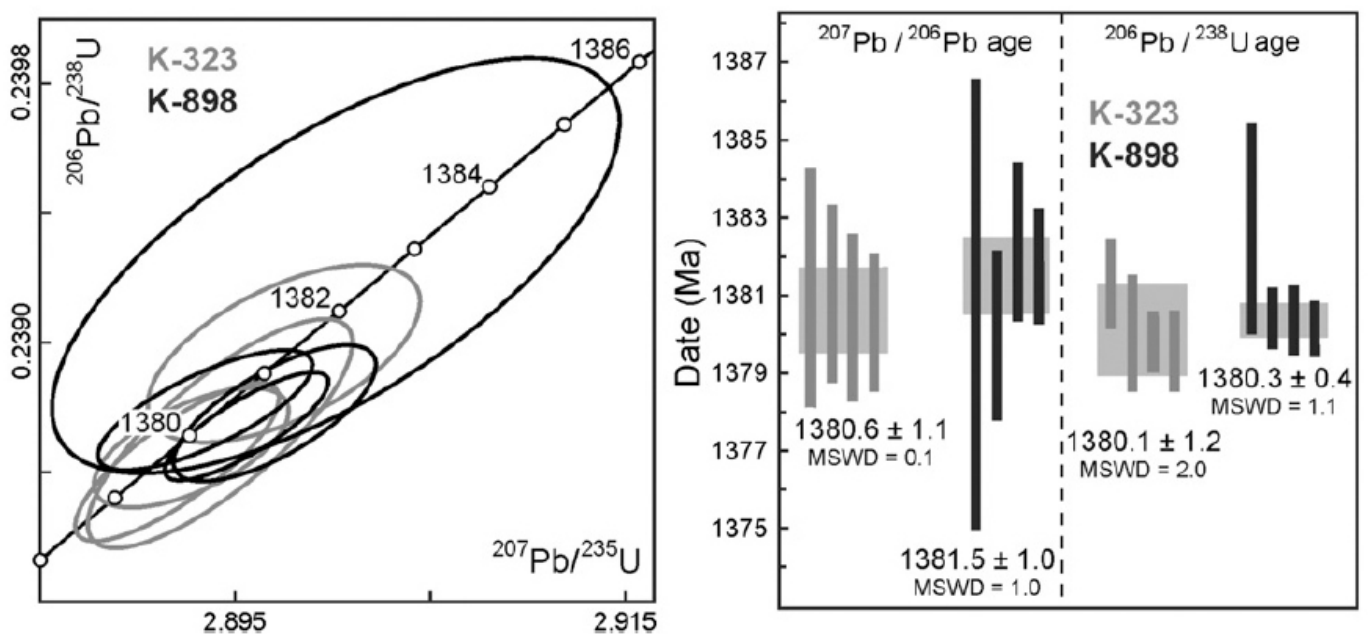

Figure 4. Concordia diagram and summaries of CA-IDTIMS isotopic data, for samples K-323 and K-808 (Puchkov et al., 2009).

and references in this paper).

A new series of U-Pb zircon analyses was made in VSEGEI (SHRIMP). An average weighted date of rhyolites for 4 samples was $1383 \pm 3 \mathrm{Ma}$; a presence of rare ancient crystals was also registered (1597 $\pm 27 \mathrm{Ma})$ (Krasnobaev et al., 2013) (Figure 5). In the same time, two samples of zircons were sent to SHRIMP in Australia (one new and one-for a control. Both gave practically the same results: $1386 \pm 5$ и $1386 \pm 6$ Ma (Puchkov et al., 2013). This laboratory has also reported a presence of some older crystals: 1420 - $1550 \mathrm{Ma}$; they are interpreted as inherited from a substrate (Figure 6).

All the dated samples are situated ca. 300 - $400 \mathrm{~m}$ above the base of the Yurmatinian series and therefore we propose the age of the boundary between the Burzyanian and Yurmatinian series at ca. 1400 Ma.

\section{Volcanics of the Arshinian Series of the Uppermost (Terminal) Riphean}

In the area of the Tirlyan syncline of the Southern Urals the Paleozoic sediments overlie unconformably a thick (up to $1.5 \mathrm{~km}$ ) series of terrigenous deposits, including tillite-like conglomerates. In the middle of the section 

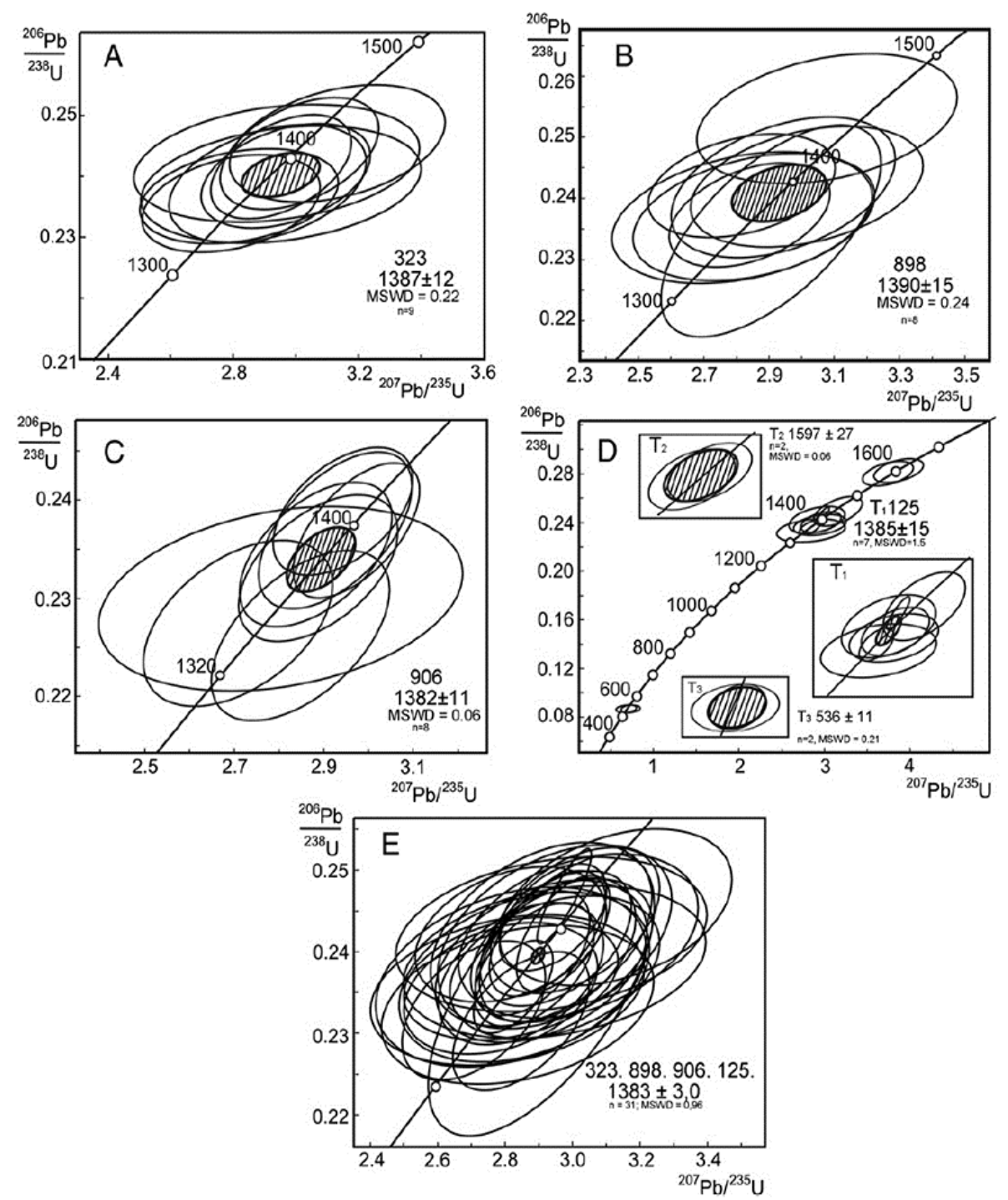

Figure 5. U-Pb ages of zircons (SHRIMP, VSEGEI) of Mashak volcanic rocks (Krasnobaev et al., 2013 b). A. Sample 323. $\mathrm{T}=1387 \pm 12 \mathrm{Ma}(\mathrm{n}=9$; MSWD $=0.22 ; \mathrm{P}=0.64)$. B. Sample 898. $\mathrm{T}=1390 \pm 15 \mathrm{Ma}(\mathrm{n}=8 ; \mathrm{MSWD}=0.24 ; \mathrm{P}=0.63)$. C. Sample 906. T3 = $1382 \pm 11 \mathrm{Ma}$ (n = 8; MSWD = 0.06; P = 0.64). D. Sample 125. T1 = $1385 \pm 15$ Ma $(\mathrm{n}=7 ; \mathrm{MSWD}=1.5 ; \mathrm{P}$ $=0.22) . \mathrm{T} 2=1597 \pm 27 \mathrm{Ma}(\mathrm{n}=2 ; \mathrm{MSWD}=0.06 ; \mathrm{P}=0.82) . \mathrm{T} 3=536 \pm 11 \mathrm{Ma}(\mathrm{n}=2$; MSWD $=0.21 ; \mathrm{P}=0.64)$. E. Samples: 323, 898, 906, 125. $\mathrm{T}=1383 \pm 3.0$ Ma $(\mathrm{n}=31$; MSWD $=0.96 ; \mathrm{P}=0.33)$. P—probability.

there is a considerable unit of volcanogenic and volcano-sedimentary deposits. It overlies with an erosional contact the Uk Formation of the Upper Riphean. Until recently, this series was described as an Arshinian Formation and attributed to the Lower Vendian (Stratigraphic schemes..., 1993). We suggested to change the rank of the unit and regard it as a series, dividing it into four Formations: Bainas, Makhmutovo, Igonino and Shumsk (Kozlov et al., 2011). The study of zircons extracted from the volcanic rocks of Igonino Formation permitted to come to a conclusion of a polychronous character of the Arshinian volcanism, with two main stages of its evolution with average levels of 707.0 \pm 2.3 and $732.1 \pm 1.7 \mathrm{Ma}$ (Krasnobaev et al., 2012) (Figure 7).

Taking into account that the age of the base of the Vendian is accepted now at $600 \pm 10 \mathrm{Ma}$ (Additional..., 2000) and opinions of the majority of specialists that allow the position of the Vendian/Riphean boundary not lower than 635 - $650 \mathrm{Ma}$, we suggest a new straton in the top of the Riphean as the Terminal, uppermost Riphean. 

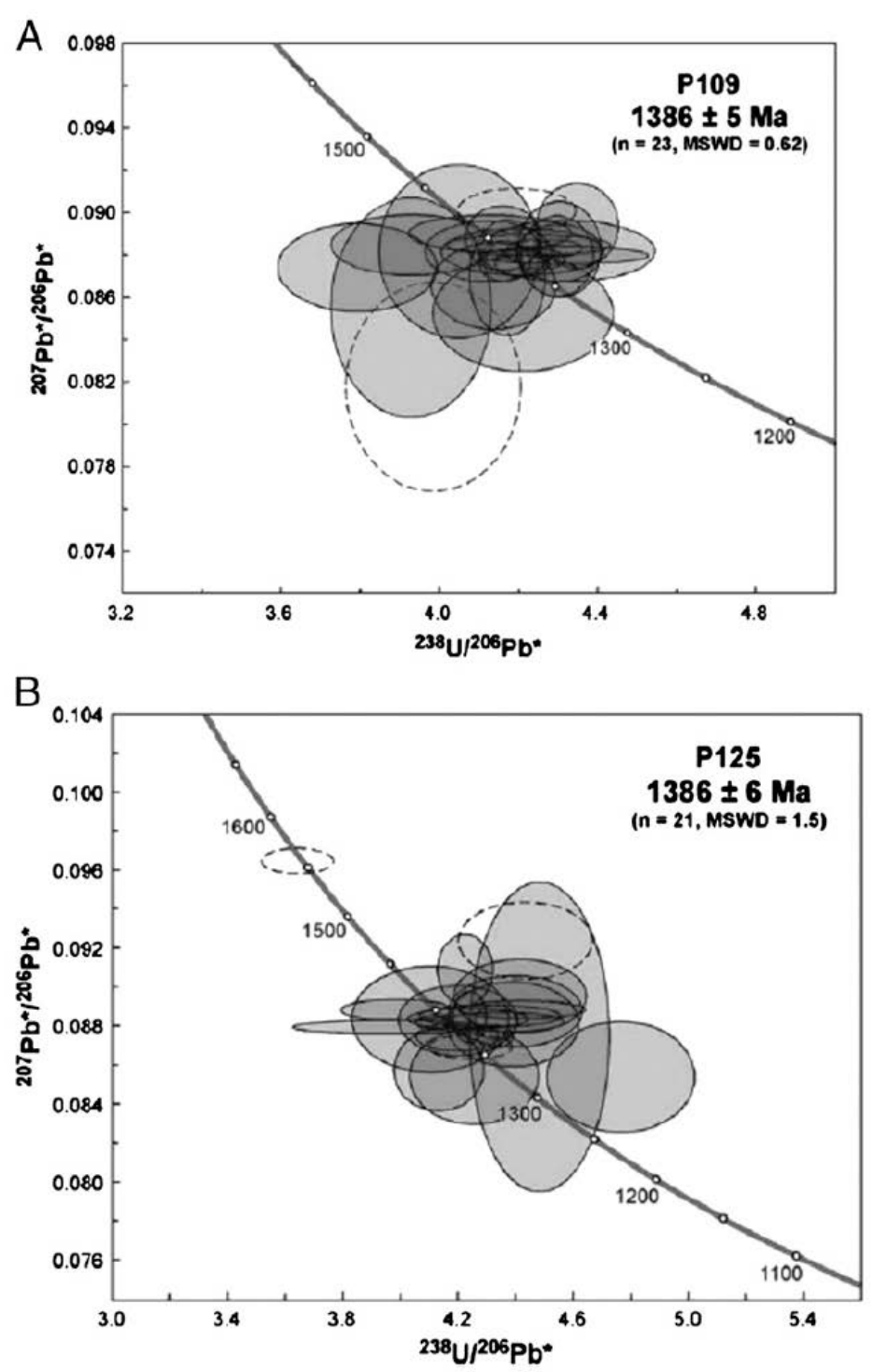

Figure 6. Analytical data for zircons, obtained in Curtin University, Australia (Puchkov et al., 2013). A. U-Pb analytical data for zircons from sample P109: Dunansungan rhyolite, Mashak Formation. Dashed ellipses indicate analyses not included in the calculation of the weighted mean $207 \mathrm{~Pb}^{*} / 206 \mathrm{~Pb}^{*}$ date, which is quoted with $95 \%$ confidence limits. B. U-Pb analytical data for zircons from sample P125: Shatak dacite-rhyolite, Mashak Formation. Dashed ellipses indicate analyses not included in the calculation of the weighted mean $207 \mathrm{~Pb}^{*} / 206 \mathrm{~Pb}^{*}$ date, which is quoted with $95 \%$ confidence limits.

\section{Conclusions}

The new dates of all three levels of development of volcanic rocks in the Riphean permit to refine considerably the stratigraphy and ages of the main stratigraphic units in the Riphean and suggest a new variant of their correlation with the ISS and Chinese Neo- and Mesoproterozoic scales. The new age determination of the lava flow of the Navysh Subformation permits to correlate a base of the Riphean with the lower boundary of the Changcheng system of China and supports the idea that the base of the Mesoproterozoic must be established at 1800 Ma.

The boundary of the Lower and Middle Riphean in the new Scheme, is approximately analogous to the Ecstasian and Calymmian boundary in the ISS or Xishan and Jixian Formations of Chinese Scheme.

The sum of geological, analytical and geochronological data permits to establish in the BMA section a new 

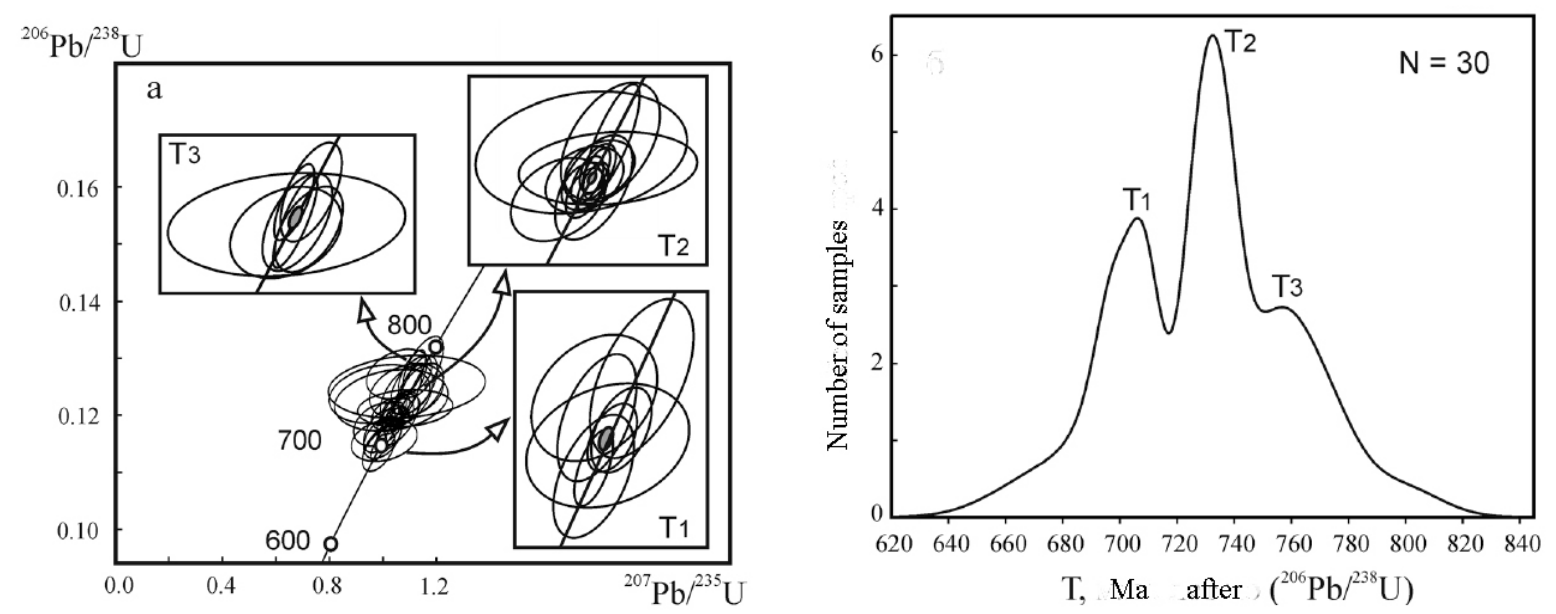

Figure 7. The age of zircons (a) distribution chart of dates with discordance $<10$ for zircons of Arsha volcanics $(\mathrm{b})$. $\mathrm{T}_{1}=$ $707.0 \pm 2.3$ млн. лет $(\mathrm{n}=9, \mathrm{MSWD}=0.54, \mathrm{P}=0.46) ; \mathrm{T}_{2}=732.0 \pm 1.7$ млн. лет $(\mathrm{n}=14, \mathrm{MSWD}=0.70, \mathrm{P}=0.40) ; \mathrm{T}_{3}$ $=762.7 \pm 4.2$ млн. лет $(\mathrm{n}=7, \mathrm{MSWD}=0.84, \mathrm{P}=0.36)$.

Table 1. Correlation of stratigraphic scales of the Proterozoic.

\begin{tabular}{|c|c|c|c|c|c|c|c|c|}
\hline \multicolumn{3}{|c|}{ International scale } & \multicolumn{3}{|c|}{ Uralian scale } & \multicolumn{3}{|c|}{ Chinese scale } \\
\hline $\begin{array}{l}\text { Eratheme, } \\
\text { Era }\end{array}$ & $\begin{array}{l}\text { System, } \\
\text { Period }\end{array}$ & Age & $\begin{array}{c}\text { Eratheme, } \\
\text { Era }\end{array}$ & & $\begin{array}{l}\text { System, } \\
\text { Period }\end{array}$ & $\begin{array}{l}\text { Eratheme, } \\
\text { Era }\end{array}$ & $\begin{array}{l}\text { System, } \\
\text { Period }\end{array}$ & Age \\
\hline \multirow{3}{*}{ Neoproterozoic } & Ediacaran & 542 & \multirow{2}{*}{\multicolumn{2}{|c|}{600}} & Vendian & \multirow{3}{*}{ Neoproterozoic } & \multirow{2}{*}{$\begin{array}{l}\text { Sinian } \\
\text { Nanhuan }\end{array}$} & \multirow{2}{*}{$\begin{array}{l}542 \\
635\end{array}$} \\
\hline & Crvogenian & 630 & & & Arshinian & & & \\
\hline & Tonian & 850 & 760 & $\begin{array}{l}\mathrm{R} \\
\mathrm{I} \\
\mathrm{P}\end{array}$ & Karatavian & & Quingbaikou & 760 \\
\hline \multirow{3}{*}{ Mesoproterozoic } & Stenian & 1000 & $\begin{array}{l}\text { Upper (Late) } \\
\text { Proterozoic }\end{array}$ & $\begin{array}{l}\mathrm{P} \\
\mathrm{H} \\
\mathrm{E}\end{array}$ & Yurmatinian & \multirow{3}{*}{ Mesoproterozoic } & unnamed & 1000 \\
\hline & Ecstasian & 1200 & \multirow{2}{*}{1400} & A & & & Xishan & 1200 \\
\hline & Calymmian & 1400 & & $\mathrm{~N}$ & & & Jixian & 1400 \\
\hline \multirow{3}{*}{ Paleoproterozoic } & Staterian & 1600 & \multirow{2}{*}{\multicolumn{2}{|c|}{1800}} & Burzyanian & \multirow[b]{2}{*}{ Paleoproterozoic } & Changcheng & 1600 \\
\hline & Orosirian & 1800 & & & & & Hutuo & 1800 \\
\hline & & & $\begin{array}{l}\text { Lower (Early) } \\
\text { Proterozoic }\end{array}$ & & & & & \\
\hline
\end{tabular}

straton: Arshinian (Uppermost, or Terminal Riphean, $\mathrm{RF}_{4}$ ) in the interval of 600 - 760 Ma. The Uppermost Riphean is correlated approximately with the Cryogenian of the ISS or Nanhuan Formation of China (Table 1).

According to provisional data (Puchkov et al., 2013, Puchkov, 2013), the time levels of volcanism of 1750 $1780 \mathrm{Ma}$ and 1380 - $1385 \mathrm{Ma}$ are widely developed on continental blocks of the Nuna (Columbia) supercontinent at the moments of its amalgamation and beginning of its break-up, which may be connected with the superplume activity of a short duration (Puchkov, 2013). Therefore, the suggested time boundaries of the Riphean may acquire an additional event support.

\section{Acknowledgements}

Authors are grateful to the Russian Foundation for Basic Research for a financial support (Projects No 1205 0070-9-a and 09-05-00845-a.

\section{References}

(1983). The Stratotype of the Riphean. Stratigraphy. Geochronology. Moscow: Nauka, 230 p. (in Russian). 
(1993). Stratigraphic Schemes of the Urals (Precambrian, Paleozoic). Ekaterinburg: Mezhv. Stratigr. Kom. Rossii. (in Russian)

(2006). Field Trip Guide on the Proterozoic of the Southern Urals. St. Petersbourg: VSEGEI. (in Russian)

Bleeker, W. (2004). Towards a “Natural” Time Scale for the Precambrian—A Proposal. Lethaia, 37, 219-222. http://dx.doi.org/10.1080/00241160410006456

Ernst, R. E., Pease, V., Puchkov, V. N. et al. (2006). Geochemical Characterizaion of Precambrian Magmatic Formations of the Southeastern Margin of the East European Craton, Southern Urals, Russia. Geologicheski Sbornik (Geological Proceedings) 5. Institute of Geology, Ufimian Sci, Centre RAS, 119-161. (In Russian)

Gao, L. Z., Geng, S. F., Jing, X. Z., Liu, Y. X., \& Zhang, H. (2012). New Geological Time Scale of Proterozoic in China. A Presentation. Beijing.

Gradstein, F., Ogg, J. G., Schmitz, M., \& Ogg, G. (2012). The Geologic Time Scale. Amsterdam: Elsevier, 1307 p.

Grazhdankin, D. V., Marusin, V. V., Meert, J., Krupenin, M. T., \& Maslov, A. V. (2011) Kotlin Regional Stage in the South Urals. Doklady Earth Sciences, 440, 1222-1226.

Kozlov, V. I. (2002). Geological Survey Map 1: 1000 000, scale N-40-41 (Ufa). St Petersburg: VSEGEI Map printing Office (In Russian).

Kozlov, V. I., Puchkov, V. N., Krasnobaev, A. A. et al. (2011). Arshinian-A New Straton of the Riphean in the Stratotypical Sections of the Southern Urals. Geologicheski Sbornik (Geological Proceedings) 9. Institute of Geology, Ufimian Sci, Centre RAS. 3-8. (in Russian)

Krasnobaev, A. A., Bibikova, E. V., Ronkin, Yu. L., \& Kozlov, V. I. (1992). Geochronology of Volcanites of the Ai Formation and Isotopical Age of the Riphean Lower Boundary. Izv. Akad. Nauk SSSR, Ser. Geol., 6. 25-41. (in Russian)

Krasnobaev, A. A., Bibikova, E. V., Stepanov, A. I., Kirnozova, T. I., Ronkin, Yu. L., Makarov, V. A., Lepikhina, O. P., \& Kravtsov, A. V. (1985). The Age of the Effusives of the Mashak Formation and the Problem of Isotope-Geochronological Boundary of the Lower-Middle Riphean. In Isotope Dating of Processes of Volcanism and Sedimentation (pp. 162-175). Moscow: Nauka. (In Russian)

Krasnobaev, A. A., Kozlov, V. I., Puchkov, V. N., Busharina, S. V., Berezhnaya, N. G., \& Nekhorosheva, A. G. (2011). Zirconology of Iron Quartzites of the Taratash Complex (Southern Urals). Doklady Earth Sciences, 437, 527-531. http://dx.doi.org/10.1134/S1028334X11040192

Krasnobaev, A. A., Kozlov, V. I., Puchkov, V. N., Busharina, S. V., Sergeeva N. D., \& Paderin I. P. (2013b). Zircon Geochronology of Mashak Volcanics and the Age of the Lower-Middle Boundary (Southern Urals). Stratigraphy. Geological correlation, 21, 465-481. http://dx.doi.org/10.1134/S0869593813050055

Krasnobaev, A. A., Puchkov, V. N., Kozlov, V. I., Sergeeva, N. D., \& Busharina, S. V. (2012). New data on zircon geochronology of the Arshinian volcanics (SouthernUrals). Litosfera, 4, 127-139. (in Russian)

Krasnobaev, A. A., Puchkov, V. N., Kozlov, V. I., Sergeeva, N. D., Busharina, S. V., \& Lepekhina, E. N. (2013a). Zirconology of Navysh Volcanic Rocks of the Ai Suite and the Problem of the Age of the Lower Riphean Boundary in the Southern Urals. Doklady Earth Sciences, 448, 185-190. http://dx.doi.org/10.1134/S1028334X13020050

Levashova, N. M., Bazhenov, M. L., Meert, J. G., Kuznetsov, N. B., Golovanova, I. V., Danukalov, K. N., \& Fedorova, N. M.. (2013). Paleogeography of Baltica in the Ediacaran: Paleomagnetic and Geochronological Data from the Clastic Zigan Formation, South Urals. Prec.Res, 236, 16-20. http://dx.doi.org/10.1016/j.precamres.2013.06.006

Maslov, A. V., \& Grazhdankin, D. V. (2013). Precambrian in the Scale of Geological Time. Litosfera, 3, 151-155. (in Russian)

Puchkov, V. N. (2013). Plumes in the History of the Urals. Bull. of MOIP. Geological Section, 88, 64-73. (in Russian)

Puchkov, V. N., Bogdanova, S. V., Ernst, R., Soderlund, U. et al. (2013). The ca. 1380 Ma Mashak Igneous Event of the Southern Urals. Lithos, 174, 109-124. http://dx.doi.org/10.1016/j.lithos.2012.08.021

Puchkov, V. N., Krasnobayev, A. A., Schmitz, M., Kozlov, V. I., Davydov, V. I., Lepekhina, E. N., \& Nekhorosheva, A. N. (2009). New U-Pb Data on the Age of Mashak Formationof the Southern Urals and Their Comparative Evaluation. Geologichesky Sbornik (Geological Proceedings) 8. Institute of Geology, Ufimian Sci. Centre, Ufa, 3-14. (in Russian)

Semikhatov, M. A., Shurkin, K. A., Aksenov, E. M. et al. (1991). A New Stratigraphic Scale for the Precambrian of the USSR. Izv. Akad. Nauk SSSR, Ser. Geol., 4, 3-13. (in Russian)

Sindern, C., Ronkin, Yu. L., Hetzel, R. et al. (2006). Taratash and Aleksandrovka Metamorphic Complexes (Southern (Urals): T-t Restrictions. Inst. of Geology and Geochemistry, Uralian Branch of RAS. "Yezhegodnik-2005”, 322-330. (In Russian)

Zhamoida, A. I. (2000) Additions to the Stratigraphical Code of Russia. SPb, VSEGEI. 112 p. (in Russian) 